\title{
Analisis Yuridis Penyelesaian Sengketa Pemutusan Hubungan Kerja Terhadap Tenaga Kerja Asing Melalui Mediasi (Studi Penelitian di Dinas Tenaga Kerja Kota Batam)
}

\author{
Velis Alicia Pui \\ Magister Ilmu Hukum Universitas Batam \\ Jl. Abulyatama, No.5 Batam Center \\ Correspondence email: velispui@gmail.com
}

\begin{abstract}
Abstrak. Dalam hubungan industrial akan selalu ada kejadian yang tidak diinginkan terjadi, baik karena kesalahpahaman maupun ketidakpuasan dari salah satu pihak. Jika telah diusahakan melalui perundingan namun belum menemukan jalan damai, maka ditempuh jalan lain, salah satunya mediasi. Penyelesaian perselisihan pemutusan hubungan kerja (PHK) ini di tempuh melalui proses mediasi di Dinas Tenaga Kerja Kota Batam oleh mediator. Mediator adalah salah satu lembaga yang disediakan oleh pemerintah untuk membantu memberikan jalan keluar atas perselisihan yang terjadi antara pengusaha dan tenaga kerja. Mediasi diupayakan agar memberikan rasa keadilan dan dengan biaya yang rendah bagi pihak yang bersengketa. bila kedua belah pihak menerima anjuran maka dibuatkan perjanjian bersama dan di daftarkan ke Pengadilan Hubungan Industrial, bila kedua belah pihak tidak menerima anjuran dari mediator maka para pihak bisa mengajukan permohonan ke Pengadilan Hubungan Industrial. Pemutusan hubungan kerja harus mengacu kepada dasar hukum tentang ketenagakerjaan, di sarankan dalam perselisihan hubungan industrial agar selalu melalui cara nonlitigasi terlebih dahulu agar menghemat waktu dan biaya, jika tidak mencapai kesepakatan baru mengajukan permohonan ke Pengadilan Hubungan Industrial.
\end{abstract}

Kata Kunci: Pemutusan Hubungan Kerja; Tenaga Kerja Asing; Mediasi

\begin{abstract}
In industrial relations there will always be unwanted events that occur, either because of misunderstanding or dissatifaction from one of the parties. If it has been attemped through negotiations but has not found a peaceful way, then another way is taken, one of which is mediation. Resolving disputes over termination of employment through a mediation process in the Batam City Manpower Office by mediator. Mediator is one of the institutions provided by the government to help provide solutions to disputes that occur between employers and workers. Striving for mediation is to provide a sense of justice and at a low cost to the disputing parties. Iif both parties do not accept the advice of the mediator, the parties can submit an application to the Industrial Relations Court. The termination of employment must refer to the legal basis of employment, it is recommended in industrial relations disputes to always be through a non-litigation method in advance to save time and money, if no agreement is reached, then submit the application to the Court.
\end{abstract}

Keywords: Termination of Employment; Foreign Workers; Mediation.

\section{PENDAHULUAN}

Hubungan industrial yang harmonis, dinamis dan berkeadilan perlu diwujudkan secara optimal sesuai dengan nilai-nilai pancasila. ${ }^{1}$ Dalam hubungan industrial akan selalu terjadi perbedaan pendapat atau karena ketidakpuasan salah satu pihak baik itu pekerja maupun pengusaha, hal ini adalah masalah yang umum terjadi. Perselisihan hubungan industrial menyebabkan adanya pertentangan antara pengusaha atau gabungan pengusaha dengan pekerja atau serikat pekerja/serikat buruh. Padahal hubungan antara pengusaha dengan pekerja/buruh atau serikat pekerja merupakan hubungan yang didasari oleh kesepakatan para pihak mengikatkan dalam hubungan kerja.

Dalam hubungan antar manusia pada umumnya selalu terjadi perselisihan, karena pada dasarnya manusia itu adalah makhluk yang egois. Namun selalu ada jalan keluar untuk menjaga hubungan antar sesama dalam menyelesaikan perselisihan.. ${ }^{2}$

Dalam Undang-Undang No. 2 Tahun 2004 mengenai Penyelesaian Hubungan Industrial disebutkan dalam Pasal 1 angka 1 bahwa: "Perselisihan hubungan industrial adalah perbedaan pendapat yang mengakibatkan pertentangan antara pengusaha atau gabungan pengusaha dengan pekerja/buruh atau serikat pekerja/serikat buruh karena adanya perselisihan mengenai hak, perselisihan kepentingan, perselisihan pemutusan hubungan kerja dan perselisihan antar serikat pekerja/serikat buruh dalam satu perusahaan mengenai hak, perselisihan kepentingan, perselisihan pemutusan hubungan kerja dan perselisihan antar serikat pekerja/serikat buruh dalam satu perusahaan"

Karena Indonesia merupakan salah satu anggota dari organisai perdagangan dunia, yaitu organisasi internasional yang mengatur perdagangan internasional yang lebih di kenal dengan nama World Trade Organization

\footnotetext{
${ }^{1}$ Undang - Undang Nomor 2 Tahun 2004 Tentang Penyelesaian Perselisihan Hubungan Industrial (Lembaran Negara Republik Indonesia Tahun 2004 Nomor 6)

${ }^{2}$ R. Joni Bambang, Hukum Ketenagakerjaan, Pustaka Setia, Bandung, 2013, Halaman 289
} 
(WTO). Maka demi mengikuti perkembangan jaman baik dibidang teknologi maupun penyesuaian peradaban, penggunaan tenaga kerja asing tidak dapat di hindari. Oleh sebab itu dibutuhkan peraturan perundang-undangan untuk mengatur segala hal yang berhubungan dengan tenaga kerja asing. Peraturan yang dibuat harus memperhatikan semua pihak yang berhubungan yaitu, pegusaha, tenaga kerja bahkan pemerintahan.

Salah satu peraturan yang dibuat yaitu peraturan Menteri Nomor PER.02/MEN/III/2008 yang mengatur tentang Tenaga Kerja Asing (selanjutnya disingkat TKA) dibuat untuk menghindari terjadinya masalah hukum baik dalam hal lapangan kerja, upah, hak dan kewajiban TKA dan faktor-faktor lain serta menjaga keseimbangan antara tenaga kerja asing dengan tenaga kerja lokal.

Ketika suatu peraturan dibuat untuk memberikan kepastian hukum, dan diundangkan secara pasti karena mengatur secara jelas (dapat dipahami dan tegas) dan logis (masuk akal, rasional) sehingga tidak menimbulkan bentrok atas ketidakpastia hukum. Menurut Sudikno Mertokusuma ${ }^{3}$, kepastian hukum adalah jaminan bahwa hukum dijalankan, bahwa yang berhak menurut hukum dapat memperoleh haknya dan bahwa putusan dapat dilaksanakan.

kepastian hukum adalah salah satu asas untuk memberikan keadilan, dengan adanya kepastian hukum diharapkan tidak menghambat pekerjaan dan menciptakan ketertiban, dengan adanya kepastian hukum hal-hal yang telah di atur oleh Undang-Undang semoga dapat bekerja secara efektif.

Tenaga kerja asing yang di pekerjakan di Indonesia baik jabatan dan jangka waktu harus jelas dalam hubungan kerja. Hubungan kerja antara seorang pengusaha dan pekerja atas dasar perjanjian kerja wajib dilakukan sesuai dengan isi dalam perjanjian kerja yang telah disetujui bersama dan tidak menyalahi Undang-Undang. Hubungan yang terjalin dalam perjanjian kerja yang memuat unsur tentang kerja, upah dan perintah inilah yang disebut hubungan kerja.

Perjanjian kerja diatur dalam Bab IX Undang-Undang Nomor 13 Tahun 2003 tentang Ketenagakerjaan. Pasal 1 Angka 14 Undang-Undang Nomor 13 Tahun 2003 tentang Ketenagakerjaan menyatakan bahwa perjanjian kerja adalah perjanjian antara pekerja/buruh dengan pengusaha atau pemberi kerja

Pemerintah juga membuat peraturan perundang-undangan yang khusus untuk mengatur tentang tenaga kerja asing di Indonesia, yaitu Undang - Undang Nomor 3 Tahun 1958 tentang penempatan Tenaga Asing, atau lebih dikenal sebagai Undang-Undang tentang Penempatan Tenaga Asing. Peraturan ini dibuat untuk mendorong kemajuan perekonomian nasional, membuka lapangan kerja melalui penanaman modal dari pihak asing, dimana pihak asing sebagai pihak investor kadang harus mendatangkan pekerja dari negara asalnya baik atas pertimbangan keahlian maupun kepercayaan.

Berikut ini adalah permasalahan yang terjadi antara tenaga kerja asing yang di rekrut oleh salah satu perusahaan di Batam, yaitu Mr. Frantz Olivier Atsou Radel, warga negara Australia yang di kontrak oleh sebuah perusahaan, karena pihak pemberi kerja memberhentikan Mr. Frantz Olivier Atsou Radel yang di rekrut sejak tanggal 03 Desember 2018 untuk jangka waktu 2 (dua) tahun sesuai dengan kontrak kerja di tanda tangani bersama dengan jabatan Facility Health Safety Environment and Security Manager tiba-tiba di putuskan hubungan kerjanya pada tanggal 16 Desember 2019 sebelum masa kontrak berakhir, dan alasan pemutusan kontrak secara sepihak adalah karena restrukturisasi organisasi, Mr. Frantz Olivier Atsou Radel tidak terima dan merasa dirugikan di tambah lagi perusahaan tidak mau membayar ganti rugi sebesar upah sampai batas waktu jangka berakhirnya jangka waktu perjanjian kerja, mengacu kepada ketentuan Pasal 62 Undang-Undang Nomor 13 Tahun 2003 yang menyatakan "Apabila salah satu pihak mengakhiri hubungan kerja sebelum berakhirnya jangka waktu yang ditetapkan dalam perjanjian kerja waktu tertentu, atau berakhirnya hubungan kerja bukan karena ketentuan sebagaimana dimaksud dalam pasal 61 ayat (1), pihak yang mengakhiri hubungan kerja diwajibkan membayar ganti rugi kepada pihak lainnya sebesar upah pekerja/buruh sampai batas waktu berakhirnya jangka waktu perjanjian kerja". ${ }^{4}$ Artinya bahwa pihak yang memutuskan hubungan kerja sebelum masa kontrak kerja berakhir, wajib membayar sisa masa kerja sebesar upah bulanan yang diterima pekerja dikali jumlah masa kerja masih tersisa. Pemutusan hubungan kerja sepihak yang membawa ketidakpuasan bagi pihak yang diberhentikan dan merasa tidak ada keadilan, membuat pihak tenaga kerja asing ini menuntut ganti rugi upah sesuai sisa kontrak dan biaya sewa rumah yang telah dibayar di depan untuk dua tahun. Namun pihak pengusaha tidak ingin membayarnya karena sesuai dengan perjanjian kerja, mereka berhak memberhentikan karyawannya jika melakukan kesalahan berat dengan mengganti satu bulan gaji saja. Permasalahan yang tidak mendukung kebijakan ini karena Mr. Frantz tidak melakukan kesalahan apapun, maka sama-sama bertahan pada prinsipnya dan tidak mencapai jalan keluar, sehingga kedua belah pihak sepakat menempuh jalan dengan meminta tolong kepada pihak ketiga yaitu mediator. Mediator adalah orang yang bekerja di bawah pemerintah untuk membantu para pekerja dan pengusaha, dalam hal ini mediator harus mendengarkan dulu keduabelah pihak, tidak berusaha membela pihak manapun, semampunya memberikan jalan keluar yang adil bagi kedua belah pihak. Dalam menyelesaikan perselisihan antara pengusaha dan pekerja pihak mediator selalu berusaha mengacu kepada UndangUndang ketenagakerjaan yang berlaku.

\footnotetext{
${ }^{3}$ Sudikno Mertokusumo, 2007, Mengenal Hukum Suatu Pengantar, ed ke-3 cet. Ke-1, Yogyakarta: Liberty, Hal. 13

${ }^{4}$ Pasal 61 Undang-Undang Negara Republik Indonesia No. 13 Tahun 2003 Tentang Ketenagakerjaan
} 
Dan dalam perselisihan ini, pihak pengusaha sebagai pihak yang memutuskan hubungan kerja sebelum jangka waktu kontrak kerja berakhir, wajib membayar kepada Mr. Frantz selaku pekerja yang diberhentikan sebesar nilai gaji bulanan di kali 11.5 bulan masa kerja tersisa"

\section{METODE \\ Pendekatan Penelitian}

Metode adalah cara sedangkan penelitian adalah proses mencari kebenaran terhadap suatu fenomena, jadi metode penelitian adalah suatu cara untuk mencari jalan keluar tentang suatu permasalahan. Dalam Penelitian ini bersifat deskriptif analisis, yaitu penelitian yang mengusahakan untuk melukiskan fakta-fakta yang nyata dan keadaan yang berkenaan dengan permasalahan pemutusan hubungan kerja sebelum masa kontrak berakhir dan tanpa membayar ganti rugi sesuai perundang-undangan, kenyataan tersebut dianalisis secara objektif berkenaan dengan ketentuanketentuan terkait dihubungkan dengan teori-teori dan praktek dalam peran mediator sebagai penengah bagi pihak yang bersengketa. Metode pendekatan yang digunakan dalam penelitian ini adalah pendekatan yuridis normatif dan didukung dengan pendekatan yuridis empiris, bahwa pendekatan ini dilakukan dengan mempelajari dan mempelajari norma-norma hukum yang berlaku, terutama yang berkenaan dengan peran mediator dalam menyelesaikan perselisihan sengketa pemutusan hubungan kerja serta sikap pengusaha dan pekerja yang berselisih.

\section{Sumber Data Dan Alat Pengumpulan Data}

Sumber data dalam penelitian ini adalah data primer dan data sekunder. Data primer bersumber dari hasil wawancara kepada pihak Dinas Tenaga Kerja Kota Batam sebagai pihak mediator dari tim hubungan industrial, pengusaha dan tenaga kerja asing. Pengumpulan data sekunder dilakukan melalui penelitian kepustakaan dengan cara mengkaji buku-buku, jurnal, hasil penelitian, dan peraturan perundang-undangan serta melalui media internet yang berhubungan dengan masalah penelitian. Bahan hukum tersier yaitu bahan-bahan yang memberikan informasi tentang bahan hukum primer dan bahan hukum sekunder seperti kamus dan ensiklopedia, majalah popular, surat kabar maupun jurnal ilmiah lainnya. ${ }^{5}$ Adapun bahan tersier yang digunakan dalam penelitian ini adalah Kamus Besar Bahasa Indonesia dan jurnal ilmiah lainnya.

\section{Lokasi, Populasi dan Sampel \\ Lokasi}

Lokasi penelitian adalah di kantor Dinas Tenaga Kerja Kota Batam karena cara penyelesaian perselisihan hubungan industrial antara pengusaha dan pihak tenaga kerja asing ini menempuh cara mediasi yang di lakukan oleh mediator dari pihak Dinas Tenaga Kerja Kota Batam.

\section{Populasi}

Populasi adalah sekelompok orang, kejadian, sesuatu yang mempunyai karakteristik tertentu. ${ }^{6}$ Dalam penelitian ini populasinya adalah pengusaha, tenaga kerja asing, pihak dinas tenaga kerja, Undang-undang Negara Republik Indonesia Nomor 13 Tahun 2003

\section{Sampel}

Responden atau subjek penelitian adalah pihak-pihak yang dijadikan sebagai sampel dalam sebuah penelitian. Dalam penelitian ini para sampel adalah pihak tenaga kerja asing, pengusaha, pengacara dan pihak mediator yaitu Dinas Tenaga Kerja.

\section{Analisis Data}

Data yang dikumpulkan, diteliti dan ditetapkan dari hasil penelitian, dan dianalisis secara kualitatif dan disajikan secara deskriptif yaitu penelitian yang diharapkan dapat memberikan gambaran tentang analisis yuridis mengenai penyelesaian sengketa pemutusan hubungan kerja oleh pengusaha terhadap tenaga kerja asing melalui proses mediasi oleh dinas tenaga kerja di kota batam.

${ }^{5}$ Soerjono Soekanto dan Sri Mamuji, Penelitian Hukum Normatif : Suatu Tinjauan Singkat, Raja Grafindo Persada, Jakarta, 1994, Hal. 13

${ }^{6}$ Jimmy Rumengan, Azuar Juliandi, Muammar Khaddafi dan Angelina Eleonara Rumengan, Metode Riset, Sefa Bumi Persada, Lhokseumawe,Cet.ke-1,2019, Hal. 43 


\section{HASIL DAN PEMBAHASAN}

Menurut Mutiara S. Panggabean, Pemutusan Hubungan Kerja (PHK) merupakan pengakhiran hubungan kerja antara pekerja dan pengusaha yang dapat disebabkan oleh berbagai macam alasan, sehingga berakhir pula hak dan kewajiban di antara mereka. ${ }^{7}$

Perselisihan dalam hubungan industrial adalah perbedaan pendapat yang mengakibatkan pertentangan antara pengusaha atau gabungan pengusaha dengan pekerja/buruh atau serikat pekerja/buruh karena adanya perselisihan hak, perselisihan kepentingan, perselisihan pemutusan hubungan kerja (PHK) dan perselisihan antarserikat pekerja/serikat buruh hanya dalam satu perusahaan (Pasal 1 angka 1 UUPPHI). ${ }^{8}$ Dari pengertian tersebut, maka dapat dilihat bahwa ada 4 (empat) jenis perselisihan hubungan industrial, yaitu :

1. Perselisihan hak

Merupakan perselisihan yang timbul karena tidak terpenuhinya hak, akibat adanya perbedaan pelaksanaan atau perbedaan penafsiran terhadap peraturan perundang-undangan, perjanjian kerja, peraturan perusahaan atau perjanjian kerja bersama (Pasal 1 ayat 2 UUPPHI).

2. Perselisihan Kepentingan

Disebabkan tidak adanya kesesuaian pendapat atas syarat-syarat kerja dalam maka menimbulkan perselisihan yang disebut perselisihan kepentingan.

3. Perselisihan pemutusan hubungan kerja

Perselisihan pemutusan hubungan kerja merupakan perselisihan yang terjadi yang disebabkan oleh pemutusan hubungan kerja oleh salah satu pihak.

4. Perselisihan antara serikat pekerja/serikat buruh

Ini adalah masalah yang timbul yang disebabkan serikat pekerja/serikat buruh dan pengusaha tidak sepakat soal keanggotaan, serta hak dan kewajiban.

Dalam Undang-Undang ketenagakerjaan Pasal 158 No. 13 Tahun 2003 memberikan hak kepada pengusaha untuk mengeluarkan karyawannya jika terbukti melakukan kesalahan-kesalahan seperti berikut ${ }^{9}$ :

1. Mengedarkan dan memakai narkotika di lingkungan kerja, serta mabuk-mabukkan;

2. Menggelapkan barang atau uang milik perusahaan dan rekan kerja;

3. Mengancam pengusaha dan teman sekerja di lingkungan kerja;

4. Melakukan perbuatan yang melawan hukum;

5. Merusak barang milik perusahaan dan merugikan perusahaan.

6. Sengaja membiarkan rekan atau pengusaha dalam keadaan bahaya di tempat kerja;

7. Mengungkapkan rahasia perusahaan;

8. Berjudi di tempat kerja

9. Membuat keterangan palsu yang merugikan perusahaan;

Dampak pemutusan hubungan kerja sangat kompleks dan cenderung menimbulkan perselisihan, maka mekanisme dan prosedur Pemutusan Hubungan Kerja diatur sedemikian rupa agar pekerja/buruh mendapatkan perlindungan yang layak dan memperoleh hak-haknya sesuai dengan ketentuan. ${ }^{10}$

Prosedur penyelesaian perselisihan hubungan industrial terhadap pekerja/buruh yang diputus hubungan kerjanya menurut Undang-undang Nomor 2 Tahun 2004 tentang Penyelesaian Perselisihan Hubungan Industrial mengutamakan pada penyelesaian melalui bipartit, yaitu suatu bentuk perundingan antara pekerja/buruh atau serikat pekerja/serikat buruh dengan pengusaha untuk menyelesaikan hubungan industrial ${ }^{11}$

\section{Tahapan penyelesaian Perselisihan Hubungan Melalui Lembaga Luar Pengadilan Bipartit}

Lembaga ini merupakan lembaga yang terdiri dari wakil pengusaha, pekerja dan serikat pekerja. jika sebuah perusahaan tidak memiliki serikat pekerja, wakil pekerja di lembaga bipartit dipilih mewakili kelompok profesi. jika lebih dari satu serikat pekerja, wakil mereka di lembaga bipartit di tetapkan secara proporsional. Semua jenis perselisihan diupayakan diselesaikan di lembaga bipartit. ${ }^{12}$

\footnotetext{
${ }^{7}$ Mutiara S. Panggabean, Manajemen Sumber Daya Manusia, Bogor, Ghalia Indah, 2004, Hal. 121

${ }^{8}$ Ugo dan Pujiyo, Hukum Acara Penyelesaian Perselisihan Hubungan Industrial, Jakarta, Sinar Grafika, 2011, Hal. 25

${ }^{9}$ Himpunan Peraturan Perundang-undangan Republik Indonesia Tentang Ketenagakerjaan, Pustaka Mahardika, Yogyakarta

${ }^{10}$ Abdul Khakim, Dasar - Dasar Hukum Ketenagakerjaan Indonesia, Bandung, Pt. citra Aditya Bakti, 2014, Hal. 175

${ }^{11}$ Pasal 1 angka 10 Undang-Undang Nomor 2 Tahun 2004 tentang Penyelesaian Hubungan Industrial

${ }^{12}$ Departemen tenaga Kerja dan Transmigrasi Republik Indonesia dan ILO, 2001, Manual Mediasi, Konsiliasi dan Arbitrase,
} Jakarta, Hal. 15 
Proses penyelesaian sengketa di lembaga bipartit diselesaikan melalui kesepakatan dengan menandatangani surat perjanjian bersama yang ditandatangani bersama para pihak yang berselisih. Jika salah satu pihak merasa dirugikan karena pihak lain tidak menepati janji maka pihak tersebut dapat melaporkan kepada pengadilan PHI di Pengadilan Negeri setempat.

Jika tidak mencapai kesepakatan melalui bipartit, maka para pihak dapat memilih menyelesaikan perselisihannya melalui mediasi, konsiliasi atau arbitrase. dari ketiga ini apabila dicapai suatu kesepakatan, maka wajib didaftarkan di pengadilan hubungan industrial pada Pengadilan Negeri dimana sengketa itu didaftarkan.

\section{Mediasi}

Mediasi adalah proses negosiasi pemecahan masalah di mana pihak luar yang tidak memihak (impartial) dan netral bekerja dengan pihak yang bersengketa untuk membantu mereka memperoleh kesepakatan dengan memutuskan. ${ }^{13}$ Sedangkan menurut Gary Goodpaster, mediasi adalah proses negosiasi pemecahan masalah di mana pihak luar yang tidak memihak (impartial) dan netral bekerja dengan kesepakatan perjanjian dengan memuaskan. ${ }^{14}$ Sedangkan menurut Mas Ahmad Santosa dan Anton L.P. Hutapea, mediasi adalah negosiasi yang dihadiri oleh pihak ketiga netral yang tidak memiliki kewenangan untuk memutuskan. ${ }^{15}$

\section{Konsiliasi}

Penyelesaian perselisihan melalui konsiliasi dilakukan oleh konsiliator yang terdaftar pada kantor instansi yang bertanggung jawab di bidang ketenagakerjaan Kabupaten/Kota. ${ }^{16}$ Konsiliator adalah anggota masyarakat yang telah berpengalaman di bidang hubungan industrial dan menguasai peraturan perundang-undangan ketenagakerjaan yang ditunjuk oleh Menteri melakukan konsiliasi dan anjuran tertulis kepada pengusaha dan pekerja atau serikat pekerja menyelesaikan perselisihan kepentingan dan perselisihan pemutusan hubungan kerja.

Daftar konsiliator untuk satu wilayah kerja disediakan di kantor pemerintah yang bertanggungjawab di bidang ketenagakerjaan. Atas kesepakatan para pihak yang berselisih pengusaha dan pekerja atau serikat pekerja memilih dan meminta konsiliator dari daftar konsiliator setempat untuk menyelesaikan perselisihan mereka mengenai kepentingan atau PHK.

Dalam 7 hari konsiliator harus memberikan informasi kepada pihak yang bersengketa, dan pada hari kedelapan wajib memberikan konsiliasi. Setelah sidang konsiliasi pertama, kesepakatan antara pengusaha dan pekerja dibuatkan dalam Perjanjian Bersama dalam waktu 14 hari, jika pihak yang berselisih tidak setuju, konsiliator memberikan anjuran tertulis kepada para pihak yang berselisih.

Pihak yang berselisih wajib menyampaikan balasan atas surat anjuran dari konsiliator paling lama dalam 14 hari. Jika pengusaha dan pihak pekeja menerima maka perjanjian bersama harus diselesaikan dalam 5 hari.

Jika para pihak yang berselisih menolak anjuran, pihak yang menolak menggugat pihak satunya ke Pengadilan Hubungan Industrial. konsiliator wajib menyelesaikan satu kasus perselisihan maksimum dalam 40 hari. Dalam proses konsiliasi, konsiliator dapat memanggil saksi dan saksi ahli. honorarium konsiliator, dan akomodasi serta biaya perjalanan saksi dan saksi ahli ditanggung oleh pemerintah. ${ }^{17}$

\section{Arbitrase}

Arbitrase merupakan lembaga penyelesaian perselisihan dalam hal perselisihan kepentingan, perselisihan Pemutusan Hubungan Kerja dan perselisihan antar serikat pekerja. Dalam hal pihak yang berselisih memilih 3 orang arbiter, proses penyelesaian dalam 3 hari para pihak dapat menunjuk seorang arbiter, dan paling lambat 7 hari sesudah itu, kedua arbiter tersebut menunjuk arbiter ketiga sebagai Ketua Majelis Arbiter. Dalam proses penyelesaian selalu menempuh cara melalui bipartit dulu. Arbiter wajib menyelesaikan perselisihan hubungan industrial dalam waktu 30 hari kerja sejak penandatanganan surat perjanjian penunjukan arbiter. ${ }^{18}$ Atas persetujuan kedua belah pihak yang berselisih, arbiter hanya dapat memperpanjang waktu penyelesaian paling lama 14 hari kerja. Putusan arbitrase merupakan putusan yang bersifat akhir dan tetap mempunyai kekuatan hukum yang mengikat para pihak yang berselisih.

Bila salah satu pihak tidak melaksanakan keputusan arbitrase, pihak yang dirugikan dapat mengajukan permohonan kepada Pengadilan Negeri untuk memerintahkan pihak tersebut melaksanakan keputusan arbitrase.

\footnotetext{
${ }^{13}$ Sudiarto dan Zaeni, Mengenal Arbitrase, PT. RajaGrafindo Persada, Jakarta, 2004, Hal. 16

${ }^{14}$ Garry Goodpaster, Arbitrase di Indonesia, Ghalia Indonesia, Jakarta, 1995, Hal. 11

${ }^{15}$ Mas Ahmad Santosa dan Anton L.P. Hutapea, Mendayagunakan Mekanisme Alternatif Penyelesaian Sengketa Lingkungan (MAPS) di Indonesia, Usaid \& Walhi, Jakarta, 1992, Hal. 3

${ }^{16}$ Pasal 17 Undang-Undang Nomor 13 Tahun 2003 Tentang Ketengakerjaan

${ }^{17}$ Ibid Hal. 17-18

${ }^{18}$ Pasal 40 Undang-Undang No. 13 Tahun 2003, Tentang Ketenagakerjaan
} 
Velis Alicia Pui, Analisis Yuridis Penyelesaian Sengketa Pemutusan Hubungan Kerja Terhadap Tenaga Kerja Asing Melalui Mediasi (Studi Penelitian di Dinas Tenaga Kerja Kota Batam)

Dalam waktu paling lama 30 hari sejak keputusan arbiter, salah satu pihak dapat mengajukan permohonan peninjauan kembali kepada Mahkamah Agung, hanya apabila :

1. Surat atau dokumen yang diajukan dalam pemeriksaan ternyata diakui atau terbukti palsu;

2. Pihak lawan terbukti secara sengaja menyembunyikan dokumen yang bersifat menentukan dalam pengambilan keputusan;

3. Keputusan arbitrase terbukti didasarkan pada tipu muslihat pihak lawan;

4. Putusan melampaui kewenangan arbiter;

5. Putusan bertentangan dengan peraturan perundang-undangan. ${ }^{19}$

\section{Tahapan penyelesaian Perselisihan Hubungan Industrial Melalui Lembaga Pengadilan Pengadilan Hubungan Industrial}

Adalah pengadilan khusus yang dibentuk dilingkungan pengadilan negeri yang berwenang memeriksa, mengadili, dan memberi putusan terhadap penyelesaian perselisihan hubungan industrial. ${ }^{20}$

Jika sudah menempuh jalan mediasi dan konsiliasi namun masih belum menemukan titik damai antara kedua belah pihak yang berselisih, untuk selanjutnya para pihak bisa menempuh jalan lain yaitu melalui gugatan ke pengadilan hubungan industrial. Pengadilan hubungan industrial bertugas untuk mengadili perselisihan hubungan industrial, perhubungan yang timbul akibat adanya perselisihan hak, perselisihan kepentingan, perselisihan antar serikat pekerja/serikat buruh, juga termasuk perselisihan pemutusan hubungan kerja, serta menerima permohonan dan melakukan eksekusi terhadap perjanjian bersama yang dilanggar oleh salah satu pihak.

\section{Mahkamah Agung}

Supaya penyelesaian sengketa bisa di selesaikan secara efektif dan efisien, Pengadilan Hubungan Industrial tidak memberikan kesempatan untuk mengajukan upaya banding ke Pengadilan Tinggi. Putusan Pengadilan Hubungan Industrial pada Pengadilan Negeri yang menyangkut perselisihan hak dan perselisihan pemutusan hubungan kerja dapat langsung dimintakan kasasi ke Mahkamah Agung. Putusan Pengadilan Hubungan Industrial pada Pengadilan Negeri yang menyangkut perselisihan kepentingan dan perselisihan antar serikat pekerja/serikat buruh dalam satu perusahaan merupakan putusan tingkat pertama dan terakhir yang tidak dapat dimintakan kasasi ke Mahkamah Agung. ${ }^{21}$

Pengaturan hukum atas penyelesaian sengketa pemutusan hubungan kerja oleh pengusaha terhadap tenaga kerja asing melalui proses mediasi di Dinas Tenaga Kerja (Studi Penelitian di Dinas Tenaga Kerja Kota Batam)

Pemutusan hubungan kerja (PHK) pernah diatur dalam beberapa peraturan perundang - undangan, namun lebih jelas dan komprehensif diatur dalam Undang - Undang Nomor 13 Tahun 2003 tentang ketenagakerjaan pada bab XII. Ketentuan Pemutusan Hubungan Kerja dalam Undang - Undang Negara Republik Indonesia Nomor 13 Tahun 2003 meliputi pemutusan hubungan kerja yang terjadi di badan usaha yang berbadan hukum atau tidak, milik orang perseorangan, milik persekutuan atau milik badan hukum, baik milik swasta maupun milik negara, maupun usaha usaha sosial dan usaha - usaha lain yang mempunyai pengurus dan mempekerjakan orang lain dengan membayar upah atau imbalan dalam bentuk lain. ${ }^{22}$

Pemutusan hubungan kerja yang dilakukan oleh pengusaha terhadap saudara Frantz Olivier Atsou Radel tidak sesuai dengan peraturan perundang-undangan ketenagakerjaan yaitu Undang-Undang Negara Republik Indonesia Tahun 1945 Nomor 13 Tahun 2003. Bahwa mengacu kepada ketentuan pasal 62 Undang- undang Nomor 13 Tahun 2003 "jika salah satu pihak mengakhiri hubungan kerja sebelum sebelum masa kontrak berakhir, dan bukan karena kesalahan berat maka pihak yang mengakhiri hubungan kerja wajib membayar ganti rugi sebesar sisa masa kontrak".

Alasan pemutusan hubungan kerja dari pengusaha adalah strukturisasi organisasi dan hanya mengganti upah sebesar satu bulan gaji, saudara Frantz Olivier Atsou Radei tidak menerima dan menempuh cara penyelesaian melalui lembaga non litigasi yaitu mediasi dari Dinas Tenaga Kerja kota Batam, pihak mediator dalam menangani kasus ini telah merujuk kepada Undang-Undang Negara Republik Indonesia Nomor 13 Tahun 2003 tentang ketenagakerjaan. Penyelesaian perselisihan hubungan industrial ini berdasarkan Undang-Undang No. 2 Tahun 2004, dalam hal ini tidak ada perbedaan antara Warga Negara Indonesia maupun Tenaga Kerja Asing.

\footnotetext{
${ }^{19}$ Ibid, Hal. 18-19

${ }^{20}$ Indonesia, Undang-Undang Republik Indonesia Nomor 2 Tahun 2004 tentang Penyelesaian Perselisihan Hubungan Industrial, Pasal 1 butir (17)

${ }^{21}$ Undang-Undang Republik Indonesia Nomor 2 Tahun 2004 tentang Penyelesaian Perselisihan Hubungan Industrial

${ }^{22}$ Asri Wijayanti, Perlindungan Hukum bagi pekerja yang di PHK karena melakukan kesalahan berat, Surabaya, Legality
} Jurnal Ilmiah Hukum, 2004 
Penyelesaian perselisihan hubungan industrial dengan cara mediasi yang dilakukan oleh seorang mediator sesuai dengan yang diatur pada pasal 15 Undang-Undang No. 2 Tahun 2004. Dengan adanya Undang-Undang ini telah memberikan jaminan kemanfaatan dan kepastian hukum melalui cara-cara penyelesaian sengketa di luar pengadilan dengan sistem yang cepat, efisien dan hemat biaya.

\section{Kendala Dalam Penyelesaian Sengketa Pemutusan Hubungan Kerja Terhadap Tenaga Kerja Asing Melalui Proses Mediasi Di Dinas Tenaga Kerja (Studi Penelitian Di Dinas Tenaga Kerja Kota Batam)}

Kendala-kendala dalam menangani penyelesaian perselisihan hubungan industrial antara pengusaha dan tenaga kerja asing adalah adanya perbedaan sudut pandang, keengganan untuk memahami apa yang disampaikan oleh mediator, tidak menerima pendapat mediator (ego tinggi para pihak). Mediator berusaha memberikan pemahaman dengan menjelaskan dengan merujuk kepada undang-undang yang berlaku, kadang mengalami kesulitan karena pihak yang bersengketa masih tidak mengeri hukum. Disinilah peran mediator sangat di butuhkan, keberadaan mediator sebagai pihak ketiga, sangat tergantung pada kepercayaan yang diberikan para pihak untuk menyelesaikan sengketa mereka. ${ }^{23}$

Mekanisme pelaksanaan mediasi dalam penyelesaian sengketa pemutusan hubungan kerja di Dinas Tenaga Kerja kota Batam telah sesuai dengan prosedur Undang-Undang No. 2 Tahun 2004 tentang penyelesaian perselisihan Hubungan Industrial dan sebelum ke ranah mediasi telah menempuh penyelesaian secara bipartit namun tidak ada kesepakatan". ${ }^{24}$

Terkait peranan mediator sebagai pihak penengah dalam perselisihan hubungan industrial antara pengusaha dan tenaga kerja asing (Frantz Oliver Atsou Radei), bapak Agus Wibowo selaku mediator hubungan industrial telah berusaha agar perselisihan ini bisa di selesaikan di tingkat mediasi melalui pendekatan sesuai dengan ketentuan (mengutamakan kemanusiaan dengan tujuan keadilan bagi kedua belah pihak). namun makna adil susah di artikan bagi kedua belah pihak, karna adil bagi satu pihak berarti ada pihak lain merasa tidak adil, maka itu diperlukan Undang-Undang sebagai rujukannya.

Berdasarkan hasil penelitian ini pihak pengusaha dan tenaga kerja asing tidak mencapai kesepakatan dalam perselisihan, dngan kata lain, anjuran dari mediator tidak diterima oleh pengusaha, dengan mengacu kepada UndangUndang No. 13 Tahun 2003 tentang ketenagakerjaan, pekerja minta ganti rugi sesuai dengan jumlah upah sebesar sisa kontrak, namun pengusaha hanya ingin membayar 1 bulan gaji dengan mengacu pada perjanjian kerja, karena tidak mencapai kesepakatan maka penyelesaian perselisihan ini di lanjutkan ke Pengadilan Hubungan Industrial.

Melalui Undang-Undang Republik Negara Indonesia Nomor 13 Tahun 2003, politik hukum pemerintah bermaksud membenahi aturan hukum ketenagakerjaan/hukum perburuhan materil agar bisa menyesuaikan dengan tuntutan kebutuhan masyarakat, sedangkan melalui Undang-Undang Republik Negara Indonesia Nomor 2 Tahun 2004 tentang penyelesaian perselisihan hubungan industrial, pemerintah dalam hal ini pembentuk Undang-Undang ingin merevisi masalah-masalah yang berhubungan dengan ketenagakerjaan/perburuhan, yaitu mekanisme penyelesaian perselisihan sengketa hubungan industrial, yang tujuan utamanya adalah untuk pencerahan dalam mewujudkan keadilan dalam hal penyelesaian perselisihan hubungan industrial.

Dalam perspektif keadilan, jika salah satu pihak merasa adil pasti ada salah satu pihak yang merasa tidak adil,maka akan susah untuk mewujudkan keadilan bagi kedua belah pihak. Namun sebagai pihak penengah hanya bisa berusaha agar adil dalam arti sama-sama menerima keputusan bersama atas dasar rela menerima konsekuensi dari hasil kesepakatan walaupun salah satu merasa keberatan, namun karena ada hukum yang mengaturnya, mereka harus menghormati hukum yang berlaku dan menaatinya.

Dengan tidak mengabaikan unsur-unsur dari tujuan hukum, yaitu keadilan, kepastian dan kemanfaatan, lembaga nonlitigasi mediator telah berusaha semaksimal mungkin untuk memberikan jalan keluar kepada kedua belah pihak yang bersengketa yaitu pihak pengusaha dan pekerja (tenaga kerja asing; Frantz olivier atsou radei) agar pihak pengusaha membayar upah sebesar sisa kontrak selama 11 (sebelas) bulan, dimana pihak tenaga kerja telah menerima namun dari pihak pengusaha merasa keberatan. Pihak pengusaha hanya mau membayar upah sebesar 1 (satu) bulan dengan alasan telah diatur dalam perjanjian kerja, sebaliknya pihak tenaga kerja juga tidak menerima tawaran dari pihak pengusaha.

Jika para pihak yang bersengketa menerima anjuran dari mediator maka akan dibuatkan surat perjanjian bersama, dan surat perjanjian bersama dan surat perjanjian itu di daftarkan ke pengadilan hubungan industrial untuk mendpatkan kekuatan hukum.

\footnotetext{
${ }^{23}$ Wawancara dengan Bapak Agus Wibowo, Tim Mediator Hubungan Industrial, di Dinas Tenaga Kerja Kota Batam, Tanggal 13 Mei 2020, Jam 10.00-12.00

${ }^{24}$ Wawancara dengan Bapak Agus Wibowo, Tim Mediator Hubungan Industrial, di Dinas Tenaga Kerja Kota Batam, Tanggal 13 Mei 2020, Jam 10.00-12.00
} 
Namun, karena sama-sama tidak ada kesepakatan, dan kedua belah pihak tidak menerima anjuran dari pihak mediator, akhirnya perselisihan ini di lanjutkan ke tingkat pengadilan hubungan industrial. Pengadilan hubungan industrial merupakan pengadilan khusus yang memeriksa, mengadili dan memutuskan putusan terhadap perselisihan hubungan industrial.

Hakim pengadilan hubungan industrial akan membantu para pihak yang bersengketa dalam hubungan industrial, menerima permohonan dari pihak yang membutuhkan, mengadili mereka serta melakukan eksekusi jika salah satu pihak tidak menepati janji.

\section{SIMPULAN}

Berdasarkan uraian yang telah dikemukakan diatas ,dan penelitian di Dinas Tenaga Kerja Kota Batam mengenai penyelesaian sengketa pemutusan hubungan kerja terhadap tenaga kerja asing (Frantz olivier atsou radei , maka penulis dapat menarik kesimpulan :

1. Pengaturan hukum terhadap penyelesaian sengketa pemutusan hubungan kerja melalui mediasi terdapat pada Undang-undang Nomor 2 Tahun 2004 tentang penyelesaian perselisihan hubungan industrial, penyelesaian perselisihan hubungan industrial melalui mediasi cukup membantu pihak tenaga kerja asing dalam menyelesaikan perselisihan industrialnya sehingga memberikan manfaat kepada mereka, manfaat penyelesaian perselisihan hubungan industrial melalui mediator antara lain proses cepat dan tanpa biaya. Dengan demikian melalui mediasi dinas tenaga kerja memberikan manfaat sehingga memenuhi asas kemanfaatan hukum.

2. Implementasi penyelesaian sengketa pemutusan hubungan kerja melalui mediasi sudah sesuai dengan peraturan perundang-undangan yaitu Undang-undang Nomor 2 Tahun 2004 tentang penyelesaian perselisihan hubungan industrial, melalui mediasi dinas tenaga kerja memberikan manfaat sehingga memenuhi asas kemanfaatan hukum baik sebagai sarana sosial engineering untuk mencapai ketertiban sosial atau berusaha mengubah perilaku manusia pada tujuan yang ingin dicapai, dengan demikian hukum dapat berfungsi untuk mengendalikan masyarakat dan bisa juga menjadi sarana untuk melakukan perubahan-perubahan yang dinginkan.

3. Kendala-kendala dalam penyelesaian perselisihan hubungan industrial yang diselesaikan melalui mediasi yaitu, antara kedua belah pihak yang bersengketa tidak menerima pendapat mediator dan masing-masing mempunyai sudut pandang yang berbeda, sesuai dengan Undang-undang Nomor 13 Tahun 2003 pihak mediator memberikan anjuran kepada pengusaha untuk melaksanakan kewajibannya kepada tenaga kerja asing, dalam hal ini ganti rugi sebesar upah pekerja sampai batas waktu berakhirnya jangka waktu perjanjian kerja. Dalam hal ini pihak mediator telah menjalankan asas hukum keadilan, yaitu ingin memberikan keadilan kepada tenaga kerja asing yang di putus hubungan kerja secara sepihak, namun anjuran dari pihak mediator untuk memberikan putusan yang adil bukanlah hal yang mudah, karena akan selalu ada salah satu pihak yang merasa tidak adil.

\section{DAFTAR PUSTAKA}

Bambang, R. Joni. 2013, Hukum Ketenagakerjaan, Pustaka Setia, Bandung.

Departemen tenaga Kerja dan Transmigrasi Republik Indonesia dan ILO, 2001, Manual Mediasi, Konsiliasi dan Arbitrase, Jakarta.

Fadlan, (2020) Debitors Guarantee in Providing the Convenience of Credit Agreement, International Journal Of Research Culture Society 6 (1), 159-162.

Fadlan, (2019) Government Policy Regarding Building Permits in Indonesia, International Journal Of Research Culture Society 3 (11), 150-154.

Fadlan (2019) Perkembangan Kebijakan Daerah sebagai Paradigma Dasar untuk Penentuan Kebijakan Mengelola Potensi Keberagaman, Soumatera Law Review 2 (1), 43-61.

Himpunan peraturan Perundang-undangan Republik Indonesia Tentang Ketenagakerjaan, Pustaka Mahardika, Yogyakarta.

Khakim, Abdul, 2014, Dasar - Dasar Hukum Ketenagakerjaan Indonesia, Pt. citra Aditya Bakti, Bandung.

Mertokusumo, Sudikno. 2007, Mengenal Hukum Suatu Pengantar, ed ke-3 cet. Ke-1, Liberty, Yogyakarta.

Panggabean, S. Mutiara, 2004, Manajemen Sumber Daya Manusia, Ghalia Indah, Bogor.

Ugo dan Pujiyo, 2011, Hukum Acara Penyelesaian Perselisihan Hubungan Industrial, Sinar Grafika, Jakarta.

Wijayanti, Asri, 2004, Perlindungan Hukum bagi pekerja yang di PHK karena melakukan kesalahan berat, Legality Jurnal Ilmiah Hukum, Surabaya.

Undang-Undang Negara Republik Indonesia No. 13 Tahun 2003 Tentang Ketenagakerjaan (Lembaran Tambahan Negara Nomor 39).

Undang - Undang Nomor 2 Tahun 2004 Tentang Penyelesaian Perselisihan Hubungan Industrial (Lembaran Negara Republik Indonesia Tahun 2004 Nomor 6). 